\title{
A comparative study of CIDP in a cohort of HIV-infected and HIV-uninfected patients
}

\section{OPEN}

Kaminie Moodley, FCN Pierre L.A. Bill, FCN Vinod Bhagu Patel, PhD

Correspondence to Dr. Patel: patelv@ukzn.ac.za or K. Moodley: Kaminie@live.co.za

Supplemental data at Neurology.org/nn

\section{ABSTRACT}

Objective: To investigate differences in clinical presentation, electrodiagnostic measures, CSF changes, and treatment outcome measures in HIV-infected and HIV-uninfected patients with chronic inflammatory demyelinating polyneuropathy (CIDP).

Methods: A retrospective analysis of medical records of all patients meeting the European Federation of Neurology diagnostic criteria for idiopathic CIDP was performed in 2 neuromuscular units in Kwa-Zulu Natal between 2003 and 2015.

Results: Eighty-four patients were included in the study; 39 were HIV-infected and 45 were HIVuninfected. Among the HIV-infected patients, the majority were younger, were female, and had a monophasic progressive illness. Eighty-six percent (86\%) were corticosteroid-responsive and $76 \%$ were in remission within 6-12 months requiring no further treatment. Among the HIVuninfected patients, the majority were older, were male, and had a relapsing-remitting course. Twenty-seven percent (27\%) were corticosteroid-responsive, 95\% required combination therapy, and $33 \%$ were not in remission by 18 months on therapy.

Conclusion: This study shows that HIV-infected patients with CIDP were younger, were more often female, displayed a monophasic progressive course, were highly steroid-responsive, and went into remission within 12 months of corticosteroid initiation. Neurol Neuroimmunol Neuroinflamm 2017;4:e315; doi: 10.1212/NXI.0000000000000315

\section{GLOSSARY}

AIDP = acute inflammatory demyelinating polyneuropathy; $\mathbf{A R T}=$ antiretroviral therapy; $\mathbf{B M I}=$ body mass index; $\mathbf{C I D P}=$ chronic inflammatory demyelinating polyneuropathy; ENFS = European Federation of Neurologic Sciences; IALCH = Inkosi Albert Luthuli Central Hospital; INCAT = Inflammatory Neuropathy Cause and Treatment; IQR = interquartile range; IRIS = immune reconstitution inflammatory syndrome; IVIg = IV immunoglobulin; KZN = Kwa-Zulu Natal; ODSS = Overall Disability Sum Score; PNS = Peripheral Nerve Society; T2 DM = type 2 diabetes mellitus.

Chronic inflammatory demyelinating polyneuropathy (CIDP) is an acquired demyelinating immune-mediated neuropathy. It is the most common treatable immune-mediated chronic neuropathy worldwide, with a prevalence ranging from 1 to 9 cases per $100,000 .{ }^{1-6}$

CIDP is considered an autoimmune disorder in which an aberrant immune response is directed towards components of the myelin sheath. However, the exact immunopathogenesis of the disease remains unknown. The response to immunosuppressive treatment is variable. ${ }^{7,8}$ Presently there is no biomarker to predict response to therapy. ${ }^{1}$

CIDP is known to occur in the setting of HIV, as are other immune-mediated neurologic disorders including a wide spectrum of neuropathies. ${ }^{9-16}$ It is commoner than acute inflammatory demyelinating polyneuropathy (AIDP). ${ }^{11,13,16-18}$ Despite the above, the clinical presentation, primary treatment outcomes, and electrophysiologic and histologic findings of CIDP in the setting of HIV are limited to case series and case reports. ${ }^{19-25}$ Treatment recommendations include IV immunoglobulin (IVIg) or plasma exchange to limit the risk of infections with corticosteroid use. ${ }^{7,16,17,26,27}$ Cost and coexistence of HIV-associated renal disease limits

From the Department of Neurology, University of KwaZulu-Natal, Durban, South Africa.

Funding information and disclosures are provided at the end of the article. Go to Neurology.org/nn for full disclosure forms. The Article Processing Charge was paid by Professor Bill: Research Fund.

This is an open access article distributed under the terms of the Creative Commons Attribution-NonCommercial-NoDerivatives License 4.0 (CC BY-NC-ND), which permits downloading and sharing the work provided it is properly cited. The work cannot be changed in any way or used commercially without permission from the journal. 
Figure $1 \quad$ Trial profile

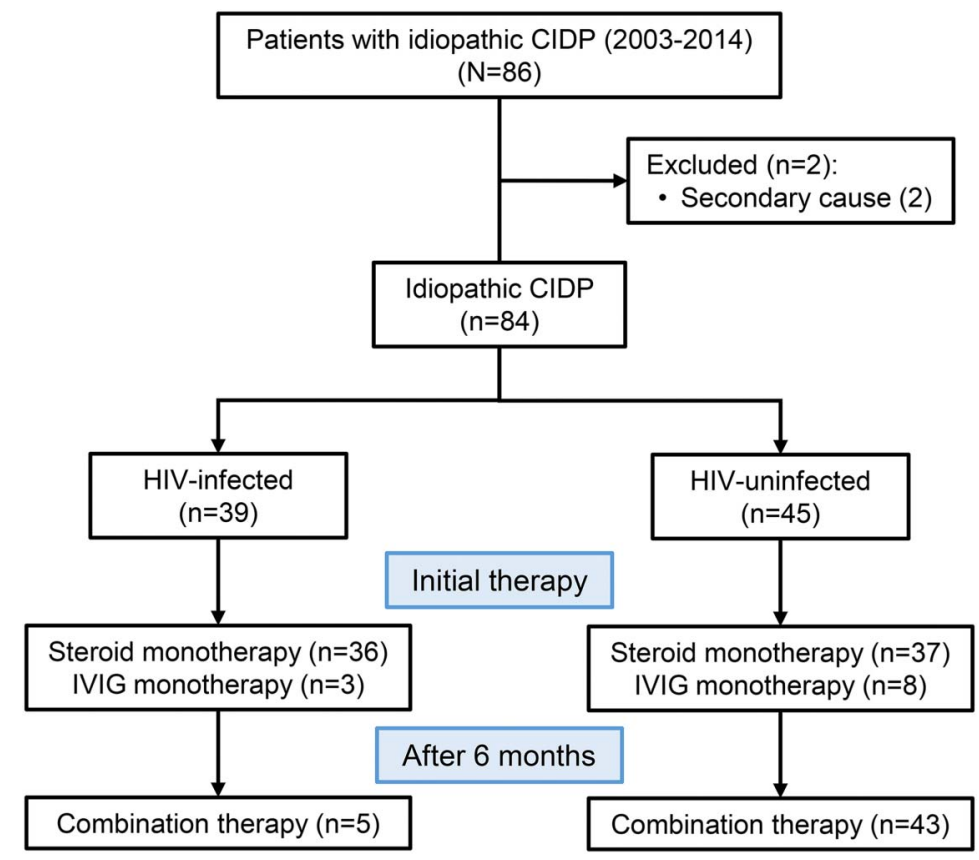

$\mathrm{CIDP}=$ chronic inflammatory demyelinating polyneuropathy; IVIg = IV immunoglobulin.

IVIg use and plasma exchange when treating CIDP. ${ }^{28,29}$ Locally, we manage HIV-infected patients with CIDP with corticosteroid therapy unless contraindicated.

Our experience suggests that HIVinfected patients with CIDP have a benign course, with few or no relapses, and respond rapidly to corticosteroid monotherapy. This suggests that the immune mechanisms in HIV-infected patients may aid recovery. The correlation between CD4 counts, viral load, and recovery is unknown.

We compared CIDP in HIV-infected and HIV-uninfected patients and describe differences between the 2 categories.

METHODS The study was a retrospective chart review of a cohort of patients with idiopathic immune-mediated CIDP from the neuromuscular clinics at Inkosi Albert Luthuli Central Hospital (IALCH) in Durban and Greys Hospital in Pietermaritzburg from 2003 to 2014. The 2 units are the only neuromuscular units in the province and provide a neurologic service to approximately 11 million people. South Africa has the highest prevalence of HIV in the world, with an estimate of 6.3 million people living with HIV in 2014. Kwa-Zulu Natal (KZN) comprises $40 \%$ of the HIV burden in South Africa. ${ }^{30}$ The study was approved by the University of KZN Biomedical Research Ethics Committee (ethics reference number: BE 272/15).

Patients fulfilling the clinical, electrodiagnostic, and CSF criteria of the European Federation of Neurologic Sciences (ENFS)/ Peripheral Nerve Society (PNS) for CIDP were included in the study (see supplementary data at Neurology.org/nn). Patients were excluded if they did not meet the diagnostic criteria for CIDP, clinical presentation was suggestive of AIDP, secondary causes were identified, or their HIV status was unknown. Data extracted included age; sex; race; duration, onset, and course of the disease; clinical presentation; antiretroviral therapy (ART) in HIV-infected patients; response to therapy, described as time to respond, number of relapses, and time to remission; degree of functional recovery, scored as Overall Disability Sum Score (ODSS) and the Inflammatory Neuropathy Cause and Treatment (INCAT) scale prior to and after treatment at 3-6 monthly intervals up to 18 months follow-up; side effects of treatment; electrophysiologic and CSF results; CD4 counts; and viral loads.

The cohort was divided into 2 categories: HIV-infected and HIV-uninfected. Within each category, patients were further classified as being corticosteroid-responsive, IVIg-responsive, or requiring combination therapy (figure 1). Definitions for the above terms including remission, lack of efficacy, as well as the management protocol followed by the neurology units at IALCH and Greys Hospital are included in the supplementary data.

Statistical methods. Data were entered in Microsoft Excel and analyzed using Prism Software. Descriptive statistics such as percentages, interquartile ranges (IQR), medians, and $p$ values were used to summarize the results in the HIV-infected and HIVuninfected patients. Tests used to calculate the above included Fisher exact test for categorical variables, Mann-Whitney $U$ test for continuous variables, and Spearman test for correlation between $\mathrm{CD} 4$ counts, viral loads, and functional scores. A $p$ value of $<0.05$ was regarded as significant.

RESULTS Eighty-six patients fulfilled the criteria for definite CIDP; 2 were excluded due to the presence of an immunoglobulin $\mathrm{M}$ paraprotein. There were 44 men and 40 women. The median age was 39.5 years (IQR 27-66). The ethnic distribution was 56 black Africans (66.7\%), 22 Indians (26\%), and 6 whites $(7.1 \%)$.

The associated etiologies in table 1 show that 10 of the $84(11.9 \%)$ patients had type 2 diabetes mellitus (T2 DM); 2 had pulmonary tuberculosis many months after the diagnosis of CIDP, probably due to long-term immunosuppression from corticosteroid use; and 2 had epilepsy. In the remaining patients, no secondary cause was identified. There was no difference in the clinical characteristics between patients with and without T2 DM (table e-1). These patients were included in the cohort.

Thirty-nine of the 84 patients (46.5\%) were HIV-infected and 45 (53.5\%) were HIVuninfected. Of the $39 \mathrm{HIV}$-infected patients, 38 were black Africans (97.5\%) and 1 was Indian (2.5\%). Sixty-one percent were female. Median age was 37 years (IQR 30-42 years). Compared to the HIV-uninfected patients, the HIV-infected patients were younger and had a female preponderance, with $p$ values of 0.0033 and 0.028 , respectively. The median CD4 count was 384 cells $/ \mathrm{mm}^{3}$ (IQR 126-423 cells $/ \mathrm{mm}^{3}$ ), median viral load was 440 copies $/ \mathrm{mL}$ (IQR 0-34,650 copies $/ \mathrm{mL}$ ). 


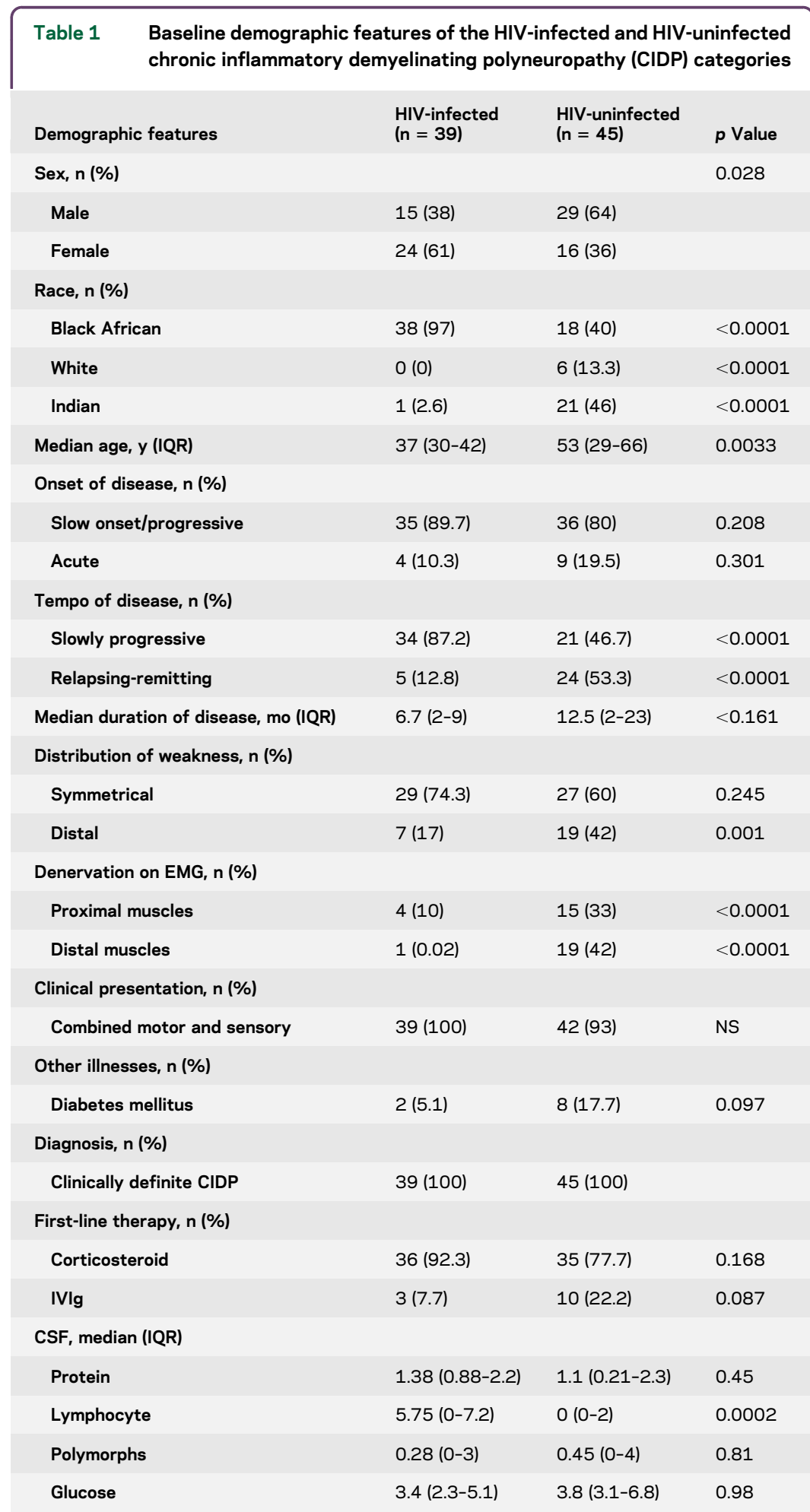

Abbreviations: IQR = interquartile range; IVIg = IV immunoglobulin.
As shown in table $1,87.2 \%$ of the HIV-infected and $46.7 \%$ of the HIV-uninfected patients presented with a monophasic progressive course ( $p \leq$ 0.0001). Median duration of illness among the HIV-infected and HIV-uninfected patients was 6.7 months (IQR 2-9 months) and 12.5 months (IQR 2-23 months), respectively ( $p=0.16$ ). Relapses frequencies were $12.8 \%$ among HIVinfected patients compared to $53.3 \%$ among HIV-uninfected patients ( $p \leq 0.0001)$. Four (10\%) HIV-infected patients and 9 (20\%) HIVuninfected patients had an acute presentation $(p=$ 0.31 ). The majority of patients in both categories had a slowly progressive onset $(p=0.21)$. Clinical signs were symmetrical in $74 \%$ and $60 \%$ of HIVinfected and HIV-uninfected patients, respectively $(p=0.245)$. Forty-two percent of HIV-uninfected patients and $17 \%$ of HIV-infected patients had distal weakness $(p=0.001)$. In both categories, the majority of patients presented with a combined sensory motor presentation. There was no difference in other clinical signs such as cranial nerve involvement, truncal weakness, tremor, or thickened nerves. No patients presented with respiratory, bulbar, or autonomic signs or symptoms.

CSF analysis (table 1) revealed a difference in lymphocyte counts between the 2 categories, with a median cell count of 5.75 cells/ $\mu \mathrm{L}$ (IQR 0-7.2 cells $/ \mu \mathrm{L}$ ) among HIV-infected patients and 0 cells $/ \mu \mathrm{L}$ (IQR 0-2 cells $/ \mu \mathrm{L}$ ) among the HIV-uninfected patients $(p=0.0002)$. Protein levels, polymorph counts, and glucose levels were not different. T2 DM was associated with raised protein levels in $90 \%$ of patients. Albumino-cytologic dissociation was present in $60 \%$ of HIV-uninfected patients and $25 \%$ of the HIV-infected patients.

Treatment, treatment outcomes, and side effects of therapy are described in table 3 and figures e-1 and e-2. Three HIV-infected patients (2 with T2 DM, 1 hypertensive) received IVIg as first-line therapy and responded within 3 months. There were no relapses or side effects.

Eighty-six percent of the HIV-infected patients were corticosteroid-responsive. Fifty-six percent responded within the first 3 months, $30.7 \%$ in 3-6 months, and $12.8 \%$ in the 6 - to 12 -month period (figure e-2). All HIV-infected patients showed a corticosteroid response by 12 months. Seventysix percent of the corticosteroid-responsive HIVinfected patients were in remission within the first 6 months (figure e-1) and $24 \%$ were in remission by 12 months. Seventy-seven percent of the HIVinfected patients were treatment-free at remission, 4 patients were on less than $5 \mathrm{mg}$ prednisone per day, and 5 patients were on a combination of azathioprine and less than $5 \mathrm{mg}$ prednisone per day. 


\begin{tabular}{|c|c|c|c|c|c|}
\hline \multirow{2}{*}{$\begin{array}{l}\text { Table } 2 \\
\text { Patient }\end{array}$} & \multicolumn{5}{|c|}{$\begin{array}{l}\text { Relationship between CD4 counts, viral loads, and onset of chronic } \\
\text { inflammatory demyelinating polyneuropathy (CIDP) }\end{array}$} \\
\hline & $\begin{array}{l}\text { Duration on } \\
\text { ARVs before } \\
\text { diagnosis, wk }\end{array}$ & $\begin{array}{l}\text { Baseline } \\
\text { CD } 4 \text { counts, } \\
\text { cells } / \mu \mathrm{L}\end{array}$ & $\begin{array}{l}\text { Baseline } \\
\text { viral loads, } \\
\text { copies/mL }\end{array}$ & $\begin{array}{l}\text { CD4 counts at } \\
\text { time of CIDP } \\
\text { diagnosis, cells/ } \mu \mathrm{L}\end{array}$ & $\begin{array}{l}\text { Viral load at the } \\
\text { time of CIDP } \\
\text { diagnosis, copies } / \mathrm{mL}\end{array}$ \\
\hline 1 & 4 & 5 & $1,820,175$ & 50 & $1,001,068$ \\
\hline 2 & 12 & 40 & 971,475 & 95 & 150,275 \\
\hline 3 & 8 & 2 & $1,203,860$ & 128 & 450,500 \\
\hline 4 & 3 & 90 & $1,004,805$ & 179 & 798,560 \\
\hline 5 & 6 & 115 & 703,805 & 260 & 306,780 \\
\hline 6 & 7 & 101 & 98,360 & 299 & 16,040 \\
\hline 7 & 4 & 126 & 58,818 & 363 & 25,428 \\
\hline 8 & 8 & 260 & 690,785 & 520 & 90,320 \\
\hline 9 & 3 & 100 & 499,980 & 188 & 300,350 \\
\hline 10 & 9 & 122 & 981,478 & 420 & 198,239 \\
\hline 11 & 244 & 95 & $1,204,707$ & 610 & Undetectable \\
\hline 12 & 300 & 126 & 75,666 & 960 & Undetectable \\
\hline 13 & 260 & 235 & 58,560 & 766 & Undetectable \\
\hline 14 & 336 & 12 & $1,950,276$ & 1,226 & Undetectable \\
\hline 15 & 320 & 187 & 880,765 & 812 & Undetectable \\
\hline $16^{a}$ & 24 & 140 & 586,866 & 100 & $1,110,000$ \\
\hline
\end{tabular}

Abbreviation: ARV = antiretrovirals.

${ }^{a}$ Treatment failure, now on second-line ARVs.

Eight of the HIV-infected patients developed an increased body mass index (BMI) during corticosteroid therapy compared to baseline. No other side effects were documented.

The functional assessment scores (INCAT and ODSS) improved significantly from high scores at presentation (patients being quadriplegic) to being almost fully functional by $6-12$ months and normal by 18 months (table e-2).

Ninety-two percent of patients had no relapses in the 18-month follow-up period. Only 3 patients had fewer than 5 relapses during follow-up (table 3 ).

Twenty-seven percent of the HIV-uninfected patients were corticosteroid-responsive. Of the $8 \mathrm{pa}-$ tients with T2 DM on IVIg, only $25 \%$ responded within 3 months. Ninety-five percent of the HIVuninfected patients required combination therapy (table 3). Twenty-two percent of patients responded to first-line therapy by 6 months, $17.8 \%$ by 12 months, $28.9 \%$ by $12-18$ months, and $33.3 \%$ showed no response to therapy (figure e-1). Twenty-four percent went into remission by $6-12$ months, $20 \%$ by $12-18$ months, and $11 \%$ after 18 months. Forty-four percent were not in remission by 18-month follow-up (figure e-2). Various combinations of therapy listed in table 3 were used to aid remission in the above patients.

The HIV-uninfected patients experienced more side effects to corticosteroids compared to the
HIV-infected patients $(p<0.0001)$. This included an increased BMI, development of a metabolic syndrome, osteoporosis, avascular necrosis of the hip, skin changes, infection, and gastrointestinal disturbances. Two patients had side effects to IVIg; 1 patient with T2 DM developed renal failure and another had a transfusion reaction (table 3). Treatment had to be discontinued. Despite therapy, the functional assessment scores in the above category showed minimal improvement after 18 months.

Among the HIV-infected patients, improving CD4 counts and decreasing HIV viral loads at 18 months did not correlate with functional recovery. Electrophysiologic studies showed no significant differences in distal motor latencies, conduction velocities, conduction block, temporal dispersion, or F-waves between the 2 categories (table e-3). However, there was a significant difference in the degree and distribution of denervation on EMG seen in the 2 categories. Only $12.8 \%$ of HIVinfected patients showed denervation in mainly proximal muscles and $75 \%$ of HIV-uninfected patients showed denervation in mainly distal muscles (table 1).

DISCUSSION HIV-infected patients showed a rapid response to corticosteroid immunotherapy with minimal relapses. In contrast, the HIV-uninfected patients were refractory to treatment. The largest study is a prospective case series consisting of 23 patients (10 HIV-infected and 13 HIVuninfected). ${ }^{19}$ This study reported no clinical or electrophysiologic differences between the 2 categories and no comparisons were made regarding treatment. Currently there are no comparative studies in the literature regarding treatment outcomes between HIV-infected and HIV-uninfected patients with CIDP. The current study showed significant differences in treatment outcomes, age, sex, and disease progression.

CIDP usually shows a male predominance, ranging from 1.31:1 to $2.8: 1$ in HIV-uninfected patients. ${ }^{19,31}$ Among the HIV-infected patients, the male: female ratio was reversed. This reversal in the sex ratio in HIV-infected patients was reported in one other study. ${ }^{19}$

The median age at onset among HIV-uninfected patients compares well to previous reported epidemiologic studies. ${ }^{3,6,32}$ Among HIV-infected patients, the median age at onset was significantly younger. The female preponderance and younger age at onset of HIV-infected patients with CIDP is an artefact of the sample and unlikely related to sex or age susceptibility as $60 \%$ of HIV-infected people in South Africa are young black females (Statistics South Africa, 2015). 


\begin{tabular}{|c|c|c|c|c|}
\hline \multirow[t]{2}{*}{ Table 3} & \multicolumn{4}{|c|}{$\begin{array}{l}\text { Response to therapy, relapses, treatment at remission, and side effects } \\
\text { to therapy in the HIV-infected and HIV-uninfected category }\end{array}$} \\
\hline & therapy & $\begin{array}{l}\text { HIV-infected, } \\
\text { n (\%) }\end{array}$ & $\begin{array}{l}\text { HIV-uninfected, } \\
\text { n (\%) }\end{array}$ & $p$ Value \\
\hline Corticost & id-responsive & $31 / 36(86)$ & $10 / 37(27)$ & $<0.0001$ \\
\hline IVlg-respc & sive & $3 / 3(100)$ & $8 / 45(17.7)$ & 0.2 \\
\hline Combinat & therapy after 6 months & $5 / 39(12.8)$ & $43 / 45(95.5)$ & $<0.0001$ \\
\hline \multicolumn{5}{|c|}{ No. of relapses in 18 months } \\
\hline 0 & & 36 (92.3) & $22(48.9)$ & $<0.0001$ \\
\hline$<5$ & & $3(7.7)$ & $9(20)$ & \\
\hline$>5$ & & 0 & $14(31)$ & \\
\hline \multicolumn{5}{|c|}{ Treatment at remission } \\
\hline No trea & ent & 30 (76.9) & 0.00 & $<0.0001$ \\
\hline$<5 \mathrm{mg}$ & rticosteroids only & $4(10.25)$ & 0.00 & \\
\hline $\begin{array}{l}\text { Corticos } \\
\text { agent }\end{array}$ & roids + corticosteroid-sparing & 5 (12.8) & $24(53.3)$ & \\
\hline Corticos & roid-sparing agent only & 0 & $2(4.4)$ & \\
\hline 3 montr & IVlg & 0 & $4(8.8)$ & \\
\hline $\begin{array}{l}\text { Combin } \\
\text { and cor }\end{array}$ & $\begin{array}{l}\text { on of corticosteroids, IVIg, } \\
\text { osteroid-sparing agent }\end{array}$ & 0 & $13(28.9)$ & \\
\hline Rituxim & & 0 & $2(4.4)$ & \\
\hline \multicolumn{5}{|c|}{ Steroid-sparing agents } \\
\hline Azathio & & 5 (12.8) & 39 (86.7) & \\
\hline Mycoph & olate mofetil & 0 & 6 (13.3) & \\
\hline Methotr & rate & 0 & $2(4.4)$ & \\
\hline Cycloph & phamide & 0 & $2(4.4)$ & \\
\hline IVlg & & 0 & 19 (42.2) & \\
\hline Rituxim & & 0 & $2(4.4)$ & \\
\hline \multicolumn{3}{|c|}{ Side effects of corticosteroids } & & $<0.0001$ \\
\hline Increas & BMI & 8 (19.1) & 33 (73.3) & \\
\hline Hyperte & ion/diabetes mellitus & 0 & 6 (13.3) & \\
\hline Osteopc & sis & 0 & 6 (13.3) & \\
\hline Skin ch & ges & 0 & $4(8.9)$ & \\
\hline Avascul & necrosis of the hip & 0 & $4(8.9)$ & \\
\hline Infectio & PTB & 0 & $2(4.4)$ & \\
\hline Gastroir & estinal & 0 & $16(35.6)$ & \\
\hline Side effec & of IVlg & & & 0.2 \\
\hline Transfu & n reaction & 0 & $1(2.2)$ & \\
\hline Renal fo & & 0 & $1(2.2)$ & \\
\hline
\end{tabular}

Abbreviations: $\mathrm{BMI}=$ body mass index; IVIg = IV immunoglobulin; PTB = pulmonary tuberculosis. to the findings of a recent study, but compatible with a previous case series consisting of 7 patients, 6 of whom had raised protein levels. ${ }^{15,19}$ High CSF protein levels reflect an immune-mediated disruption of the blood-nerve barrier at the level of the spinal roots, which correlates with proximal, possibly root involvement among the HIV-infected patients. However, the difference in protein levels did not reach statistical significance, possibly due to the short duration of the disease, small numbers, and unregulated immunity among the HIV-infected patients. As in previous studies, the HIV-infected patients had higher CSF lymphocyte counts, which are most likely related to CSF viremia rather than CIDP-related immunologic changes. This CSF finding is consistent with other studies. ${ }^{33,34}$ Despite $59 \%$ of HIV-infected patients being on ARTs, a significant number still had ongoing CSF lymphocytosis. Many of these patients had a suppressed plasma viral load. This may represent inadequate penetration of ART into the CSF space or CSF HIV resistance resulting in ongoing CSF viral replication. ${ }^{35}$

The response to corticosteroid monotherapy among HIV-infected patients was clearly demonstrated within 3 months. Most of the HIVinfected patients were in remission by 6 months. This short duration of corticosteroid therapy seems to be a safe and cost-effective option in HIVinfected patients. Current literature states that IVIg or plasma exchange is the preferred choice due to the risk of infection with corticosteroid therapy. ${ }^{8,20,22,27,29}$ However, in this study, the risk of infection was negligible with short duration of therapy. The only significant side effect documented among the HIV-infected patients was an increase in BMI. All patients had BMI documented at baseline and thereafter 3 monthly while on corticosteroids. Only HIV-uninfected patients had bone density scans as they were on long-term corticosteroids. This was not necessary among the HIVinfected patients as their duration of treatment was short.

The varying response to corticosteroid monotherapy in the 2 categories of patients suggests that the immunopathogenesis is different. Autoantibodies targeting noncompact myelin, which includes the nodes of Ranvier, paranode, and juxtaparanode regions, rather than major myelin protein such as $\mathrm{P} 0$, PMP22, may select for a relatively benign course. ${ }^{1}$ Support for antibodies in the pathogenesis was demonstrated by a good response to plasma exchange. ${ }^{25} \mathrm{~A}$ decline in HIV T-regulatory CD4 cells potentiates the emergence of autoimmune phenomena. ${ }^{36,37}$ ARTs result in immune reconstitution and upregulation of the total number of CD4 T-regulatory cells, which may contribute to remission. There is a single 
case report of CIDP resolving with ARTs alone. ${ }^{21}$ In our study, ARTs may have expedited recovery by restoring immune function.

In patients diagnosed as HIV-infected at CIDP diagnosis, ARTs and corticosteroids were commenced simultaneously. No deterioration occurred in this category. Concomitant use of corticosteroids may have potentially curtailed the immune reconstitution inflammatory syndrome (IRIS). This may be a potential avenue for future therapy in patients being initiated on ARTs. The 10 patients who had low baseline CD4 counts and high viral loads (table 2, patients 1-10) may have had CIDP as an IRIS phenomenon as they were commenced on ARTs for a short period. Patient 16, who developed immunologic and virologic failure, may have had an IRIS response when commencing secondline therapy. Presently there are no markers to predict who will develop this complication.

Five patients on long-term ARTs (table 2, patients 11-15) had complete immune reconstitution and behaved as HIV-uninfected patients with prolonged refractory disease and poor response to corticosteroids. Furthermore, the long duration of disease prior to presentation and presence of denervation on EMG indicating axonal damage (tables 1and e-4) may account for a poor response to corticosteroids.

Although AIDP was a potential diagnosis, this was discounted as all patients met the ENFS/PNS clinical and electrodiagnostic criteria for CIDP, progressed beyond 12 weeks, had typical electrodiagnostic findings for demyelination (table e-2), had no prior flulike illness or diarrheal illness, had an insidious onset, and had no bulbar, respiratory, or autonomic symptoms, and none showed spontaneous recovery during the initial 3 months of progression. The speculation that recovery may have occurred despite corticosteroid therapy can only be answered in a prospective study comparing placebo with corticosteroids. Nonetheless, patients with suspected AIDP and spontaneous recovery during the initial 3 months were excluded from the study. Furthermore, AIDP was unlikely in the 13 patients with acute-onset CIDP, as the 4 $\mathrm{HIV}$-infected patients progressed beyond 12 weeks and responded to corticosteroid therapy within 4 weeks and the $9 \mathrm{HIV}$-uninfected patients showed a poor response to corticosteroid monotherapy in the first 6 months and required combination immunosuppressive therapy.

During the above study period, we have seen approximately 100-120 HIV- infected patients with AIDP at our neurology institute, who behaved differently from our HIV-infected patients with CIDP. All patients presented acutely and $70 \%$ had a preceding flu or diarrheal illness. Approximately $30 \%$ of patients required intensive care unit admission for bulbar/respiratory involvement or autonomic instability. Spontaneous recovery was seen in about $5 \%$ of these patients. All patients were treated with IVIg and not steroids. Therefore we concluded that our cohort of patients had CIDP rather than AIDP and were corticosteroid responsive rather than manifesting spontaneous recovery.

Limitations of the study are that it is a retrospective study; numbers are small and have tertiary care setting bias. Other limitations are that many patients may have been missed as a result of not being referred or being misdiagnosed.

This study suggests that treated HIV-infected patients with CIDP have a short duration of disease, have a benign course, and are highly corticosteroidresponsive compared to their HIV-uninfected counterparts. Although we satisfy the ENFS criteria for CIDP, the quick recovery and the relatively benign monophasic course makes AIDP a possibility. Perhaps the course and progression of CIDP in HIVinfected individuals is different and revision of criteria for the diagnosis of CIDP in HIV-infected individuals is required. This study also shows that corticosteroids are a cost-effective and safe option in HIV-infected patients with CIDP, especially in a resource-limited setting. Further prospective studies confirming a rapid corticosteroid response in HIVinfected patients with CIDP as well as unraveling the immune mechanisms responsible for CIDP in these patients is required to better define future therapy.

\section{AUTHOR CONTRIBUTIONS}

Kaminie Moodley: developed concept, collected and analyzed data, generated manuscript. Vinod B. Patel: developed the concept, assisted with protocol development, analysis of data, and editing manuscript. P.L.A. Bill: reviewing manuscript, study concept or design, acquisition of data.

\section{ACKNOWLEDGMENT}

Statistical analysis was conducted by Susaan Marais, $\mathrm{PhD}$, University of KwaZulu-Natal.

\section{STUDY FUNDING}

No targeted funding.

\section{DISCLOSURES}

The authors report no disclosures. Go to Neurology.org/nn for full disclosure forms.

Received September 9, 2016. Accepted in final form October 21, 2016.

\section{REFERENCES}

1. Mathey EK, Park SB, Hughes RA, et al. Chronic inflammatory demyelinating polyradiculoneuropathy: from pathology to phenotype. J Neurol Neurosurg Psychiatry 2015;86:973-985.

2. Rajabally Y, Vital A, Ferrer X, et al. Chronic inflammatory demyelinating polyneuropathy caused by HIV infection in 
a patient with asymptomatic CMT 1A. J Peripher Nerv Syst 2000;5:158-162.

3. Manji H. Neuropathy in HIV infection. Curr Opin Neurol 2000;13:589-592.

4. McLeod JG, Pollard JD, Macaskill P, Mohamed A, Spring P, Khurana V. Prevalence of chronic inflammatory demyelinating polyneuropathy in New South Wales, Australia. Ann Neurol 1999;46:910-913.

5. Mahdi-Rogers M, Hughes RA. Epidemiology of chronic inflammatory neuropathies in southeast England. Eur J Neurol 2014;21:28-33.

6. Knopf L, Menkes DL. Comorbid HIV and myasthenia gravis: case report and review of the literature. J Clin Neuromuscul Dis 2010;12:80-84.

7. Bright RJ, Wilkinson J, Coventry BJ. Therapeutic options for chronic inflammatory demyelinating polyradiculoneuropathy: a systematic review. BMC Neurol 2014;14:26.

8. Dalakas MC; Medscape. Advances in the diagnosis, pathogenesis and treatment of CIDP. Nat Rev Neurol 2011;7: 507-517.

9. Dimachkie MM, Barohn RJ. Chronic inflammatory demyelinating polyneuropathy. Curr Treat Options Neurol 2013;15:350-366

10. Blanche P, Diaz E, Gombert B, Sicard D, Rivoal O, Brezin A. Devic's neuromyelitis optica and HIV-1 infection. J Neurol Neurosurg Psychiatry 2000;68:795-796.

11. Schutz SG, Robinson-Papp J. HIV-related neuropathy: current perspectives. HIV AIDS 2013;5:243-251.

12. Ferrari $S$, Vento $S$, Monaco $S$, et al. Human immunodeficiency virus-associated peripheral neuropathies. Mayo Clin Proc 2006;81:213-219.

13. Centner CM, Bateman KJ, Heckmann JM. Manifestations of HIV infection in the peripheral nervous system. Lancet Neurol 2013;12:295-309.

14. Pardo CA, McArthur JC, Griffin JW. HIV neuropathy: insights in the pathology of HIV peripheral nerve disease. J Peripher Nerv Syst 2001;6:21-27.

15. Cornblath DR, Hoke A. Recent advances in HIV neuropathy. Curr Opin Neurol 2006;19:446-450.

16. Robinson-Papp J, Simpson DM. Neuromuscular diseases associated with HIV-1 infection. Muscle Nerve 2009;40: 1043-1053.

17. Hahn K, Husstedt IW; Arendt GfdDN-A-A. HIVassociated neuropathies [in German]. Nervenarzt 2010;81:409-417.

18. Miller RG, Parry GJ, Pfaeffl W, Lang W, Lippert R, Kiprov D. The spectrum of peripheral neuropathy associated with ARC and AIDS. Muscle Nerve 1988;11: 857-863.

19. Mochan A, Anderson D, Modi G. CIDP in a HIV endemic population: a prospective case series from Johannesburg, South Africa. J Neurol Sci 2016;363:39-42.

20. Cornblath DR, McArthur JC, Kennedy PG, Witte AS, Griffin JW. Inflammatory demyelinating peripheral neuropathies associated with human T-cell lymphotropic virus type III infection. Ann Neurol 1987;21:32-40.

21. Kume K, Ikeda K, Kamada M, Touge T, Deguchi K, Masaki T. Successful treatment of HIV-associated chronic inflammatory demyelinating polyneuropathy by early initiation of highly active anti-retroviral therapy [in Japanese]. Rinsho Shinkeigaku 2013;53:362-366.

22. Vital A, Beylot M, Vital C, Delors B, Bloch B, Julien J. Morphological findings on peripheral nerve biopsies in 15 patients with human immunodeficiency virus infection. Acta Neuropathol 1992;83:618-623.

23. Przedborski S, Liesnard C, Voordecker P, et al. Inflammatory demyelinating polyradiculoneuropathy associated with human immunodeficiency virus infection. J Neurol 1988;235:359-361.

24. Chaunu MP, Ratinahirana H, Raphael M, et al. The spectrum of changes on 20 nerve biopsies in patients with HIV infection. Muscle Nerve 1989;12:452-459.

25. Kiprov D, Pfaeffl W, Parry G, Lippert R, Lang W, Miller R. Antibody-mediated peripheral neuropathies associated with ARC and AIDS: successful treatment with plasmapheresis. J Clin Apher 1988;4:3-7.

26. Abstracts of the joint meeting of the Italian peripheral nerve study group and the British peripheral nerve society: Trieste, Italy: April 8-10, 2010. J Peripher Nerv Syst 2010;15(suppl 1):1-40.

27. Chimowitz MI, Audet AM, Hallet A, Kelly JJ Jr. HIVassociated CIDP. Muscle Nerve 1989;12:695-696.

28. Ross MJ, Klotman PE. HIV-associated nephropathy. AIDS 2004;18:1089-1099.

29. Lu TC, Ross M. HIV-associated nephropathy: a brief review. Mt Sinai J Med 2005;72:193-199.

30. Statistics SA. Statistical Release P0302: Mid-Year Population Estimates 2015 [online]. Available at: https://www. statssa.gov.za/publications/P0302/P03022015.pdf. Accessed July 1, 2016.

31. Barohn RJ, Kissel JT, Warmolts JR, Mendell JR. Chronic inflammatory demyelinating polyradiculoneuropathy: clinical characteristics, course, and recommendations for diagnostic criteria. Arch Neurol 1989;46:878-884.

32. McCombe PA, Pollard JD, McLeod JG. Chronic inflammatory demyelinating polyradiculoneuropathy: a clinical and electrophysiological study of 92 cases. Brain 1987; 110:1617-1630.

33. Gisslen M, Fuchs D, Svennerholm B, Hagberg L. Cerebrospinal fluid viral load, intrathecal immunoactivation, and cerebrospinal fluid monocytic cell count in HIV-1 infection. J Acquir Immune Def Syndr 1999;21:271-276.

34. Marshall DW, Brey RL, Cahill WT, Houk RW, Zajac RA, Boswell RN. Spectrum of cerebrospinal fluid findings in various stages of human immunodeficiency virus infection. Arch Neurol 1988;45:954-958.

35. Canestri A, Lescure FX, Jaureguiberry $S$, et al. Discordance between cerebral spinal fluid and plasma HIV replication in patients with neurological symptoms who are receiving suppressive antiretroviral therapy. Clin Infect Dis 2010; 50:773-778.

36. Eggena MP, Barugahare B, Jones N, et al. Depletion of regulatory $\mathrm{T}$ cells in HIV infection is associated with immune activation. J Immunol 2005;174:4407-4414.

37. Zandman-Goddard G, Shoenfeld Y. HIV and autoimmunity. Autoimmun Rev 2002;1:329-337. 


\title{
Neurology \\ Neuroimmunology \& Neuroinflammation
}

\author{
A comparative study of CIDP in a cohort of HIV-infected and HIV-uninfected patients \\ Kaminie Moodley, Pierre L.A. Bill and Vinod Bhagu Patel \\ Neurol Neuroimmunol Neuroinflamm 2017;4; \\ DOI 10.1212/NXI.0000000000000315
}

This information is current as of December 15, 2016

\section{Updated Information \& \\ Services \\ Supplementary Material}

References

Subspecialty Collections

Permissions \& Licensing

Reprints including high resolution figures, can be found at:

http://nn.neurology.org/content/4/2/e315.full.html

Supplementary material can be found at:

http://nn.neurology.org/content/suppl/2017/02/21/4.2.e315.DC1

This article cites 36 articles, 2 of which you can access for free at: http://nn.neurology.org/content/4/2/e315.full.html\#\#ref-list-1

This article, along with others on similar topics, appears in the following collection(s):

\section{HIV}

http://nn.neurology.org//cgi/collection/hiv

Peripheral neuropathy

http://nn.neurology.org//cgi/collection/peripheral_neuropathy

Information about reproducing this article in parts (figures,tables) or in its entirety can be found online at:

http://nn.neurology.org/misc/about.xhtml\#permissions

Information about ordering reprints can be found online:

http://nn.neurology.org/misc/addir.xhtml\#reprintsus

Neurol Neuroimmunol Neuroinflamm is an official journal of the American Academy of Neurology.

Published since April 2014, it is an open-access, online-only, continuous publication journal. Copyright

Copyright (C) 2016 The Author(s). Published by Wolters Kluwer Health, Inc. on behalf of the American

Academy of Neurology. All rights reserved. Online ISSN: 2332-7812.

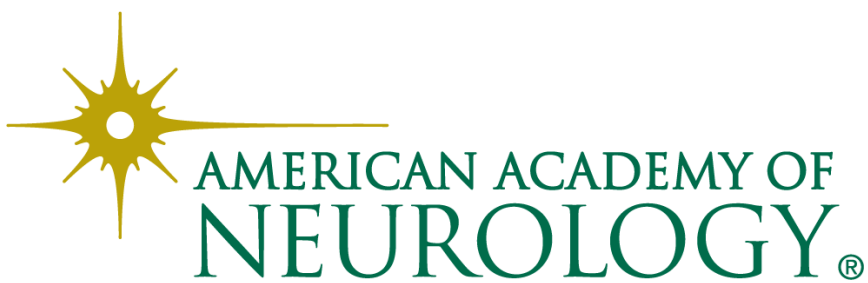

